University for Business and Technology in Kosovo

UBT Knowledge Center

UBT International Conference

2012 UBT International Conference

Nov 2nd, 9:00 AM - Nov 3rd, 5:00 PM

\title{
The Surface Distribution of Oil Spills, the Environmental Status of the Visoka Oilfield, Its Rehabilitation Ways: Case Study
}

\author{
Nevton Kodhelaj \\ Polytechnic University of Tirana, nevtonkodheli@yahoo.com \\ Aida Bode \\ Polytechnic University of Tirana, boaal@yahoo.com \\ Piro Zoga \\ Polytechnic University of Tirana, pzoga@yahoo.com \\ Nevina Koja \\ Department of Energy Resources \\ Esmeralda Zeqo \\ Department of Energy Resources
}

See next page for additional authors

Follow this and additional works at: https://knowledgecenter.ubt-uni.net/conference

Part of the Computer Sciences Commons, and the Engineering Commons

\author{
Recommended Citation \\ Kodhelaj, Nevton; Bode, Aida; Zoga, Piro; Koja, Nevina; Zeqo, Esmeralda; and Zeqiraj, Dulian, "The Surface \\ Distribution of Oil Spills, the Environmental Status of the Visoka Oilfield, Its Rehabilitation Ways: Case \\ Study" (2012). UBT International Conference. 71. \\ https://knowledgecenter.ubt-uni.net/conference/2012/all-events/71
}

This Event is brought to you for free and open access by the Publication and Journals at UBT Knowledge Center. It has been accepted for inclusion in UBT International Conference by an authorized administrator of UBT Knowledge Center. For more information, please contact knowledge.center@ubt-uni.net. 


\section{Presenter Information}

Nevton Kodhelaj, Aida Bode, Piro Zoga, Nevina Koja, Esmeralda Zeqo, and Dulian Zeqiraj 


\title{
The Surface Distribution of Oil Spills, the Environmental Status of the Visoka Oilfield, Its Rehabilitation Ways: Case Study
}

\author{
Nevton KODHELAJ ${ }^{167}$, Aida BODE ${ }^{168}$, Pirro ZOGA ${ }^{2}$, Nevina KOJA ${ }^{1}$, \\ Esmeralda $\mathrm{ZEQO}^{1}$, Dulian ZEQIRAJ ${ }^{1}$ \\ ${ }^{1}$ Department of Energy Resources, FGM, PUT, nevtonkodheli@yahoo.com \\ ${ }^{2}$ Department of Natural Resources, FGM, PUT, boaal@yahoo.com
}

\begin{abstract}
Visoka oilfield was explored in 1963 through the well G-622. In this oilfield had been drilled more than 170 production wells. Through all this years of its exploitation, mainly because of the outdated technology, the environmental pollution reached really dramatic values. The pollution extends on the Visoka village, affecting so the life for the entire community. The oil spills, the gas emissions and the formation water affected and polluted and "killed" the Gjanica River, its delta and the Adriatic coast in the Semani beach. Due to the technology and the completely wrong policies, used in the past, the wells had been equipped with a pit, whose actually are filled with oil, water and solid wastes. Now these mixtures are more similar with TAR's. This is the main evidence which proves that, the area hadnever been cleaned up properly. Actually the reservoir had been given in use to a foreigner company, based in a petroleum agreement. The concessionary has already preparing the rehabilitation plan. Based on the best international experience the cleaning up ways will be based on the oil spill treatment, mainly through dispersants, the water treatment through dispersants, filtrations processes and reinjection and the emissions cleaning up mainly through reinjection. The polluted soil will be treated through thermal methods, or will be deposited in a closed landfill. Evaluations, calculations and spatial distribution of the oil spills of the Gjanica River and Adriatic Sea are presented in this paper.
\end{abstract}

Keywords: Gjanica, Visoka, pollution, distribution, dispersants

\section{Introduction}

The Visoka oilfield is situated in one of the most geologically studied regions, because it is an oil-bearing area where many wells have been drilled, and many studies have been conducted. The exploitation section in the Visoka oilfield is the limestone of Cretaceous - Eocene age. The oil-bearing thickness of the Visoka reservoir is concentrated in these formations which from the rock property as pect, and for practical reasons, are divided into lithological packages. In the central part of the structure these deposits are eroded. The top carbonate is covered by the Marne transition zone, which is $30-35 \mathrm{~m}$ thick and are covered by a considerable thickness of flysch deposits dating Oligocene ( $\mathrm{Pg} 3)$ who's serve as an impermeable cover for storing the oil and gas reserves in the carbonate reservoir. The southern part of the structure extends toward the southeast, and forms a pericline of a quiet deepening in 10-12 ${ }^{\circ}$. This form of extension, as well as some other factors, has favored the creation of the trap, which concentrates oil and gas in this part of the structure. Its structural form was proved by the drilling of 243 wells of different purposes such as, exploration, appraisal, exploitation and contouring. In the structural viewpoint, the upper tectonic unit is a monocline that extends north-northwest, on a deepening angle in this direction of 10-12 . The Messinian deposits in the southern part, in the village of Patosi, appear in the surface where the sandstones of "Driza" suite are saturated with oxidized bituminous oil, which served as isolation screen, for preventing the further migration of oil.

\footnotetext{
${ }^{167}$ Faculty of Geology and Mining (Energy Resources Department)

${ }^{168}$ Faculty of Geology and Mining (Natural Resources Department)
} 


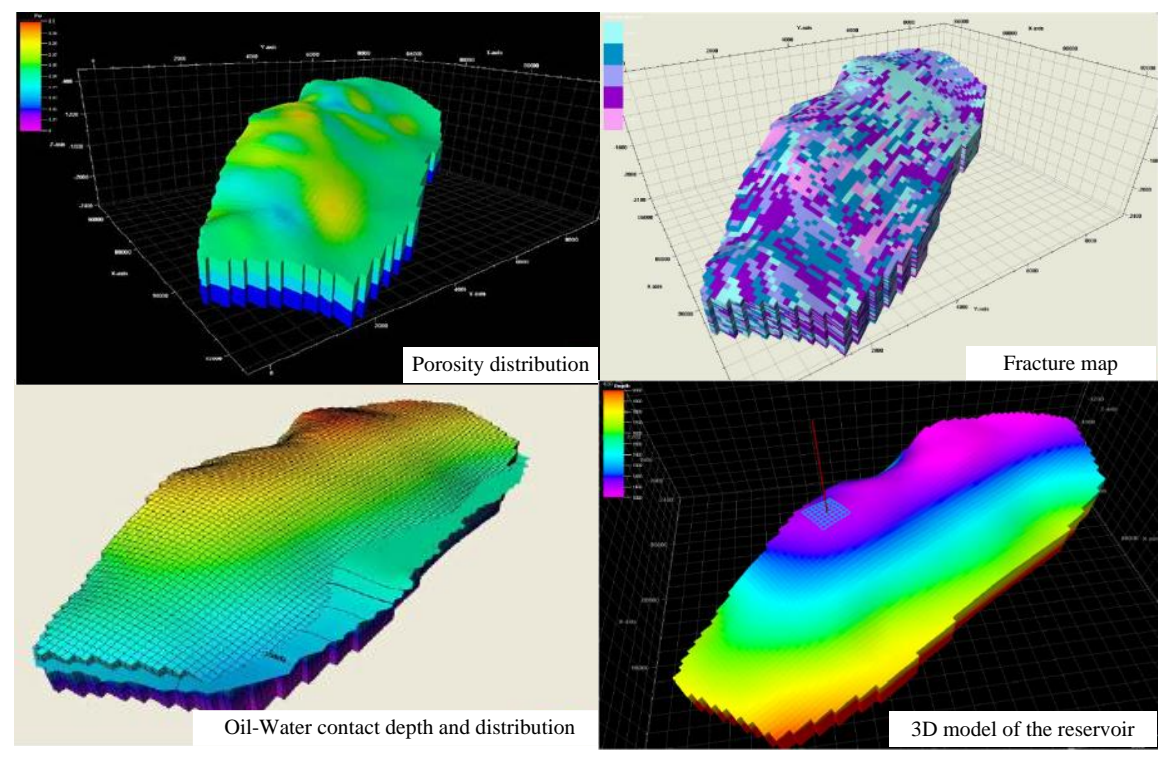

Figure 8: Visoka oilfield maps

\subsection{Environmental status of the Visoka oilfield (baseline survey)}

The majority of the oil wells had "oil pools", which have a surface of some tens up to hundreds square meters and depth from $0.5 \mathrm{~m}$ to $1 \mathrm{~m}$ (referring to the level of surrounding soil). These pools were created by the continuous leakage of the wells and ordinary work over operations. In many cases livestock's and domestic birds of the farmers are trapped in the pits filled with oil and it is impossible to take them out. The oil flow and gas emission at the neck of the well had been problematic. This was result of the old, totally outdated technology and of the leakage from the wellhead equipment's. The lack of the limiting channel is lack of the preventive barriers around the wells in order to isolate these flows of oil. Except the oil spills, another extremely harmful pollutant is the formation water. The high $\mathrm{H}_{2} \mathrm{~S}$, chlorines and dissolved oil content makes it one of the biggest environmental issues on the Visoka oilfield. It can be clearly seen in the figure 2, whose shoes some interesting data's about the total, oil and water produced for approx. 43 years in Visoka oilfield. As all the produced water is discharged on the Gjanica River, which flow's to the Semani River and after it goes to the Adriatic Sea, it can be easily imagined it's high environmental impact. The pollution of these areas is of the kind: Sedimentary waters pollution; combined waters pollution (sedimentary and concomitant); Concomitant waters pollution; Concomitant waters with low mineralization and high content of oil pollution; Wastes by the oil tanks cleaning up processes.

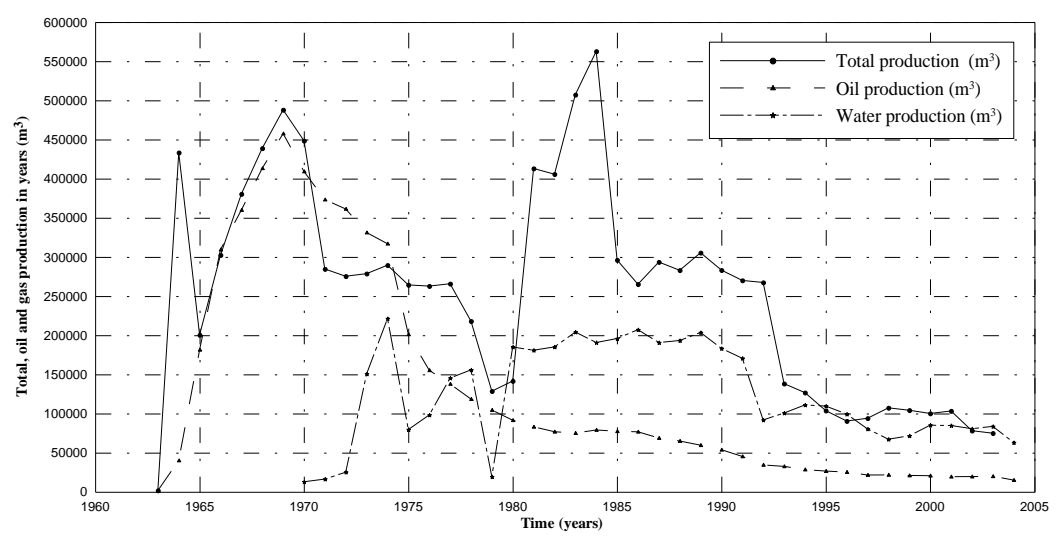

Figure 2: Vis oka oilfield maps 


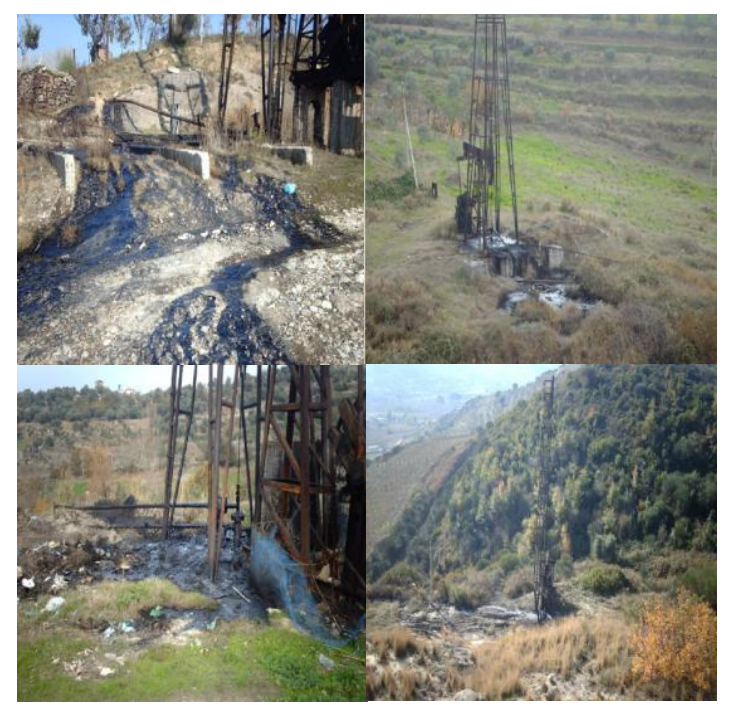

Figure 3: Production data's of the Visoka oilfield

\subsection{Production wells and groups pollution in the Visoka oilfield}

According to the initial project, each production well in Visoka oilfield should have an area of approximately $850 \mathrm{~m}^{2}$, where it is included: the wellhead, pipelines and the soil pit of $20 \mathrm{~m}^{2}$ which serves for the collection of the oil spills. The environmental situation at the Visoka oil field had been, is less to say, dramatic. In the figure 3 can be seen the pollution level of the surroundings of the producing wells and groups of the deposits of Visoka.

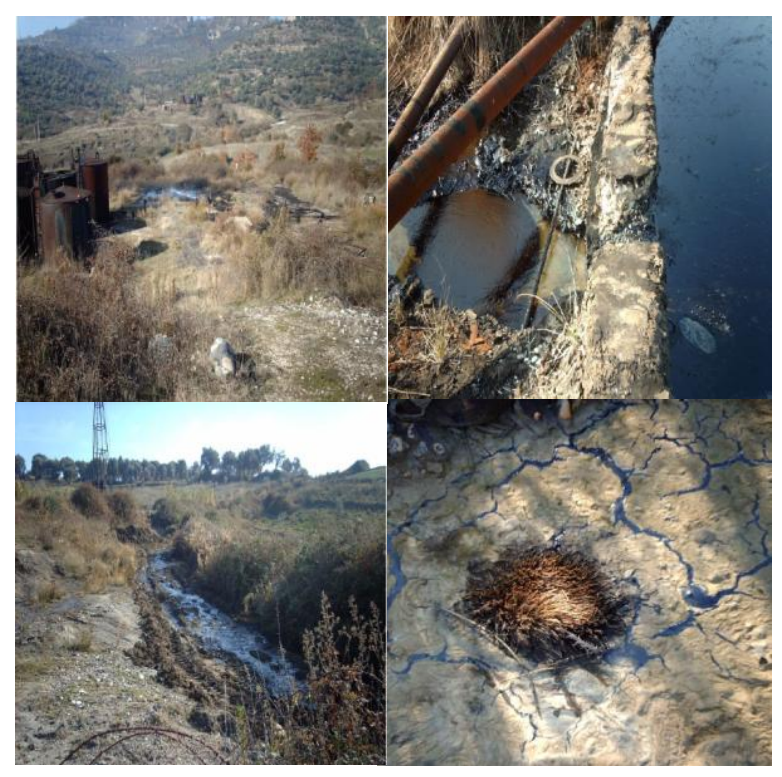

Figure 9: Territory pollution of the Visoka oilfield

\subsection{Territory pollution of the Visoka oilfield}

Due to the long-time irresponsible exploitation of this oilfield the territory status isn't better that the wells and groups. As the oilfield is placed in the middle of the village the risk is even bigger. In the figure 4 is possible to see the territ ory pollution of the Visoka village. 


\subsection{Oil spills characteristics and their chemical cleaning up process}

Characteristics of oil stains depend on many factors, ranging from the type and properties of the spilled oil, weather conditions, tidal levels and diversity of life living in the polluted area. Although any oil stain has its properties, it's a big mistake to generalize the results achieved by dispersants treatment or mechanically cleaning up. Direction of movement and spreading of oil leak is a natural process but scientifically interpreted. The speed of spread is approx. $3.5 \div 5 \%$ as the average wind speed. It depends also by the tides level in the polluted area. Vector of spread is the resultant vector of these. Its spread is also conditioned by the forces of gravity and oil surface tension. There are also a number of factors whose affect the oil stain spread as evaporation, digestion of light fractions, emulsions, oxidation and biodegradation. The evaporation and light fractions dissolving processes are associated with the emulsions creations. This process is assisted by the added mixtures or chemical transformations that accompany its biodegradation. Although emulsions are created slower than the evaporation and light fractions dissolving, as they change the nature of the spot, the problem is very serious. EIA of an oil stain is a very interesting process, even if the radius of influence is large or small. Binding of the spread in time and space of the spot with the physical, biological and chemical damage of the ecosystem is in figure 5 .

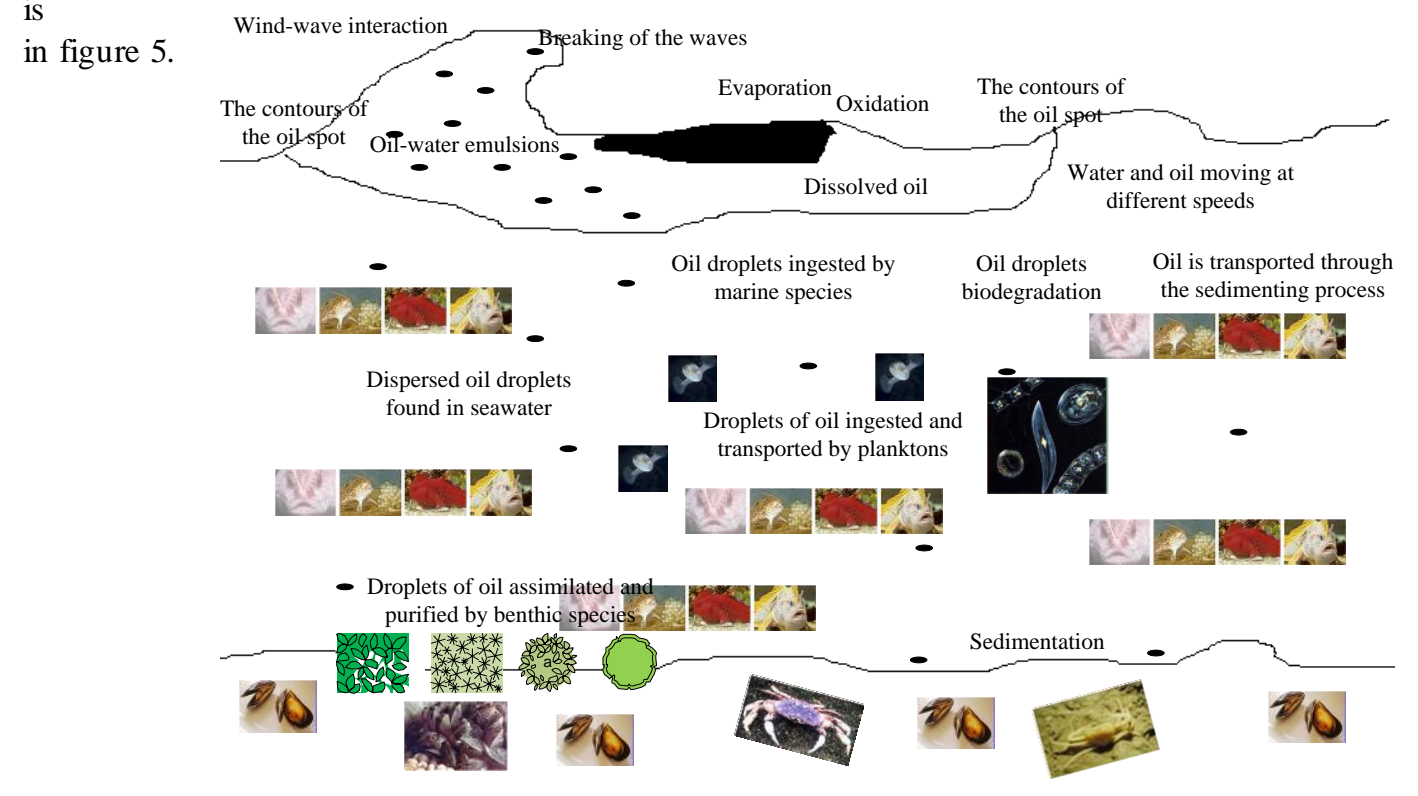
presented

Figure 5: Oil spills processes

The chemical dispersants can be used in: Oil production and rigs (platforms) maintenance; Oil spills dispersion in order to protect personnel and the equipment's in cases of uncontrolled eruptions; Ships and tankers neutralization; Accidental spills neutralization; Roads accidents with trucks/tanks; Large spills aerial spraying; Oceans/seas/river/lakes oil stains dispersion; Enhancement of Oil Production. The dispersants are divided into three main groups: Water based products, Solvents and Concentrates. They differ from each-otherby the easy of the oil dispersion (creation of small droplets). Water based products require a longer time for the spills processing, depending on their quantity. The solvent, used for the heavy oil treatment are more effic ient, but requires very high doses. Concentrates, especially the mixed types, share oil in very small droplets and require minimal amounts of energy to realize it. In any case, dispersants treatment should be considered as secondary choice. It should be applied only when the mechanical cleaning is not possible, or do not give the required results. In some cases they can be applied simultaneously (Gulf of Mexico etc.). As the overdosing dilute the oil spill and therefore increase the speed at which it moves, thus increasing the contaminated area, great care should be taken in the doses calculation. In some cases is better to use smaller quantities, that what has resulted from the calculations, and leave to the water to complete its own cleaning. 


\section{Source of the pollution in the visoka oilfield and their treatment 2.1Air pollution}

Due to the facts that the Visoka reservoir is saturated with oil, dissolved gas and other gases (especially $\mathrm{H}_{2} \mathrm{~S}$ ) the atmospheric pollution had been really problematic. The problem can be solved through the use of the appropriate production facilities, starting from adequate packing of the well to the installing of new separation station. Based on the gas/oil factor which is estimated to be approx. $29.3 \mathrm{~nm}^{3} / \mathrm{m}^{3}$, it can be clearly seen the economic efficiency of these processes, without counting the environmental protection.

\subsection{Polluted soil treatment and results}

Based on the number of production wells in Visoka oilfield ( 240 wells drilled and exploited), the fact each well had polluted approx. $850 \mathrm{~m}^{2}$ of soil up the depth of $30 \mathrm{~cm}$, it can calculated that there are around $60000 \mathrm{~m}^{3}$ of polluted soil. As it is showed before the production wells are in the middle of the village, so the problem is bigger. The best way to treat and solve this problem is the excavation of the polluted soil, up to the depth of 30 $\mathrm{cm}$ and transport it the treatment implants $[6,9]$. The treatment way in the beginning was thought to be based on the thermal methods and centrifuges. Due to the characteristics of the formation both they resulted no feasible, so it was concluded to use the biodegradation in rows. The results were really impressing. Now it is excavated the polluted soil in more than 150 wells $\left(30000 \mathrm{~m}^{3}\right)$ while is treated completely only $25 \%$ of it. The difference is placed in three ecological pits (Manekaj and Kuqari with total capacity of $25000 \mathrm{~m}^{3}$ ). The only problem is that the biodegradation is a slowly process, so now the operating company is thinking to treat it up the reduction of the pollution with $50 \%$ ( 4 months of treatment) and after to send it to one other site for further and complete treatment. Anyway the situation around the wells is completely different, and it can be clearly seen in the figure $6[2]$.

Figure 6: The results of the soil treatment (biodegradation)

\subsection{Water pollution}

The problem of the water pollution in the Visoka oilfield can be divided in two subgroups [4]: the formation water and the surface water oil contamination. The best and more efficient way to treat the formation water seems to be the reinjection. The volume of water produced in a year is really high $\left(5700 \div 5800 \mathrm{~m}^{3} / \mathrm{month}\right.$; see figure 2), while the reinjection solve not only the pollution problems (this is water with very high mineralization level), but it can be considered as an EOR. The designing of the proper web of reinjection wells is the key factor for the success of the method. The wells had been chosen mainly on the boundary, except a few cases, when the formation properties (permeability anisotropy) allowed to be re-injected even in some another wells. In total they are 25 reinjection wells, whose are able to face all the produced water volume. The Gjanica River water status, speaking in the environmental point of view, had been really tremendous. Discharged petroleum sludge is 74 tons/year, while the values for some of the most important indicators are: $\mathrm{pH}=8.3 ; \mathrm{COD}=4.8 \mathrm{mg} / \mathrm{l} ; \mathrm{BOD}=40$ $\mathrm{mg} / \mathrm{l}$; phosphates content $0.5 \mathrm{mg} / \mathrm{l} ; \mathrm{NH}_{4}$ content $0.3 \mathrm{mg} / 1[3,5]$. So it can be clearly seen that the situation had been really bad. Due to the fact that the oil sludge discharge continued for a long period of time, the pollution extended also on the riverbed, Semani river and its delta up to the Adriatic sea coastline. After analyzing all the information and the best international experience it was made the decision to treat the Gjanica river path with type 2 dispersants $[7,8]$. The dose was $98.411 / \mathrm{m}^{2}$ and it was pumped with yields of $22.7 \mathrm{l} / \mathrm{min}$. The results were 
immediate, after only 15 minutes there was no more visible oil in the surface of the water. The monitoring continued based on measurements on two levels: surface and $30 \mathrm{~cm}$ depth. The results in both cases were really excellent [10]. The oil content decreased from $0.089 \mathrm{mg} / 1$ to $0.008 \mathrm{mg} / \mathrm{l}$ at the surface, after $30 \mathrm{~min}$, while they decreased from $0.034 \mathrm{mg} / 1$ to $0.002 \mathrm{mg} / 1$ at the depth of $30 \mathrm{~cm}$. They are showed also in the figure 7 .

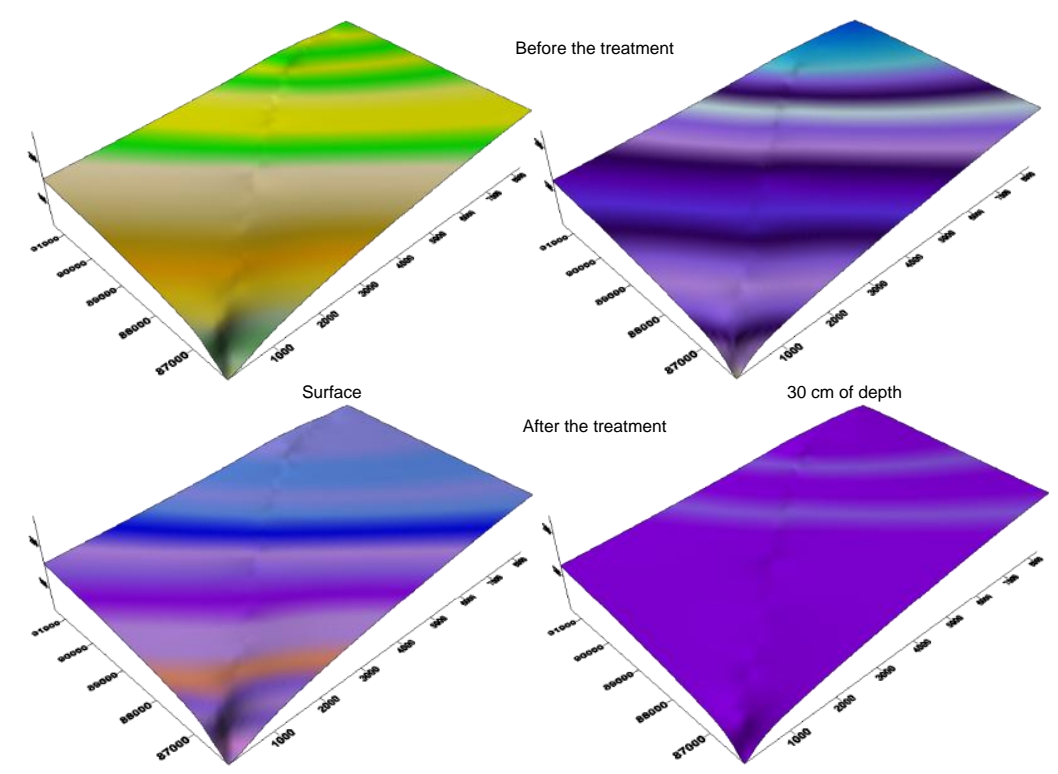

Figure 7: The oil content in the Gjanica river water before and after the treatment

\section{Conclusions}

Based in almost catastrophic territory situation in the Visoka oilfield, surface and underground waters, caused for almost 50 years of irresponsible exploitation, it was need for emergent intervention. The processes aimed and succeed in:

- Cleaning up of the contaminated soil;

- Cleaning up of the contaminated water.

To clean up the polluted soil was experimented the use of centrifuges, thermal treatment and biodegradation. The best method resulted to be the biodegradation. More than $8500 \mathrm{~m}^{3}$ of contaminated soil had been treated, while $21500 \mathrm{~m}^{3}$ had been excavated and transported to the ecologic pits, waiting for treatment. Regarding the treatment of the polluted water, based on the best practices and the researches resulted that the best way was the type 2 dispersant usage. The monitoring showed that the oil content decreased from $0.089 \mathrm{mg} / \mathrm{l}$ to $0.008 \mathrm{mg} / \mathrm{l}$ at the surface, after $30 \mathrm{~min}$, while they decreased from $0.034 \mathrm{mg} / \mathrm{l}$ to $0.002 \mathrm{mg} / \mathrm{l}$ at the depth of $30 \mathrm{~cm}$. The process should continue up to the total cleaning of the Visoka village territory, while should be respect the standards during the exploitation procedures [11].

\section{References}

[1]. Agrawal, K.M., Sikdar, P.K., Deb, S.C. A Textbook of Environment. Macmillan India Limited, Kolkata. 454 pp, 2002. 
[2]. Kodhelaj, N. AlbanianPossibilities on Geothermal Direct Utilization. Renewable and Sustainable Energy-Elsevier, vol. 15, issue 5, pages 2534-2544, 2011.

[3]. Bhagi, A., Chatwal, G.R. Environmental Chemistry. Himalaya Publishing House, Girgaon, India. 506 pp, 2003.

[4]. Bharucha, E. Textbook of Environmental Studies. Universities Press, Hyderabad, India. $276 \mathrm{pp}, 2005$.

[5]. Bhatia, S.C. Environmental Pollution and Control in Chemical Process Industries. Khanna Publishers, New Delhi. 1133 pp, 2001.

[6]. Brady, N.C. and R.R. Weil 1999. The Nature and Properties of Soils (12 th Edition), Upper Saddle River, Printice Hall, New Jersey.

[7]. Broeckner, W.S. T. Takahashi, H.J. Simpson and T.H. Peng 1979. Fate of Fossil Fuel carbon dioxide and the Global Carbon Budget. Science 206:409-418.

[8]. Brown, C.W. and Lynch, P.F., Tanker Tragedies: Identifying the Source and Determining the Fate of Petroleum in the Marine Environment. Tenth International Conference on Environmental Toxicity, Rochester, N.Y., 23-25 may 1977.

[9]. Buckman, H.O. and N.C. Brady 1984. The Nature and Properties of Soils ( $9^{\text {th }}$ Edition), Collier Mac Millan, New York.

[10]. Kodhelaj, N., Bode, A., 5-8 June 2012. Environmental status on the visoka oilfield and its rehabilitation ways, case study. International Conference on Sustainable Energy and Environmental Protection (SEEP 2012), Dublin, Ireland. Proceedings 2:291-297.

[11]. Kodhelaj, N., Koja, N., Levani, F. 2012. Ndikimet mbi mjedis të industrisë nxjerrëse të naftës, vlerësimi i mjedisit në vendburimin e visokës dhe rrugët që duhet të ndiqen për rehabilitimin e tij. Nafta Shqiptare. 1. 